\title{
PENGEMBANGAN ASPEK SOSIAL ANAK USIA DINI DI TAMAN KANAK-KANAK ABA IV MANGLI JEMBER TAHUN 2016
}

\author{
Musyarofah \\ Dosen Ilmu Pendidikan Sosial IAIN Jember \\ musyarofahhrt@yahoo.co.id
}

\begin{abstract}
Early childhood growth will affect the next period i.e. the attainment of maturity in social relations. This research would like to overview the early childhood development precisely and maximally, so the result will be able to develop all aspects of the scope of child development including social aspects. The goal in this research is to describe the early childhood social development in kindergarten (TK) ABA IV Mangli Jember by using qualitative approach. The results showed that (1) the early childhood social abilities in kindergarten ABA IV Mangli Jember include the ability to get along, socialize and properly communicate with friends and teachers, working together, being patient in taking turn, caring and helping friends who is in trouble in classroom tasks, sharing food and toys, giving up to friends and being responsible.
\end{abstract}

Keywords: Development, socially and early childhood

\begin{abstract}
Abstrak
Pertumbuhan anak usia dini akan mempengaruhi periode berikutnya yaitu pencapaian kematangan dalam hubungan sosial. Penelitian ini ingin melihat pengembangan anak usia dini secara maksimal dan tepat sasaran, sehingga mampu mengembangkan semua lingkup aspek perkembangan anak termasuk aspek sosial anak. Tujuan dalam penelitian ini untuk mendeskripsikan pengembangan sosial anak usia dini di Taman Kanak-Kanak (TK) ABA IV Mangli Jember dengan menggunakan pendekatan kualitatif. Hasil penelitian menunjukkan bahawa (1) kemampuan sosial anak usia dini di Taman Kanak-Kanak ABA IV Mangli Jember meliputi kemampuan bergaul, bersosialisasi dan komunikasi dengan teman dan guru secara baik, bekerjasama, bersabar menunggu giliran, peduli dan menolong teman yang mengalami kesulitan mengerjakan tugas di kelas, berbagi makanan dan mainan, mengalah pada teman dan bertanggungjawab.
\end{abstract}

Kata Kunci: Pengembangan, Sosial dan Anak Usia Dini 
INJECT: Interdisciplinary Journal of Communication, Vol.2, No.1, Juni 2017: h. 99-122

\section{Pendahuluan}

Anak adalah seorang individu yang unik dengan segenap potensi yang dimiliki. Anak dilahirkan belum bersifat sosial. Dalam arti, dia belum memiliki kemampuan untuk bergaul dengan orang lain. Untuk mencapai kematangan sosial, anak harus belajar cara menyesuaikan diri dengan orang lain. Kemampuan ini diperoleh anak melalui berbagai kesempatan atau pengalaman bergaul dengan orang-orang di lingkungannya, baik orang tua, saudara, teman sebaya atau orang dewasa lainnya.

Undang-Undang No. 20 tahun 2003 tentang Sistem Pendidikan Nasional menjelaskan bahwa anak usia dini adalah anak yang berada dalam rentang usia 0 tahun yaitu sejak lahir sampai 6 tahun. Hurlock (1978:38) mengemukakan bahwa anak usia prasekolah atau prakelompok disebut juga masa kanak-kanak dini yaitu anak yang berumur 2-6 tahun. Pada masa ini anak berusaha mengendalikan lingkungan dan mulai belajar menyesuaikan diri secara sosial.

Masa usia dini (0-6 tahun) merupakan masa peka yaitu masa terjadinya fungsi-fungsi pematangan fisik dan psikis yang siap merespon stimulasi yang diberikan oleh lingkungan. Masa ini adalah masa untuk meletakkan dasar pertama dalam mengembangkan kemampuan fisik, kognitif, bahasa, sosial emosional, konsep diri, disiplin, kemandirian, seni, moral, dan nilai-nilai agama (Yamin dan Sabri Sanan, 2013:3). Usia dini merupakan masa yang sangat menentukan bagi perkembangan dan pertumbuhan anak selanjutnya, mengingat masa ini merupakan masa peka, dan masa keemasan dalam kehidupan anak. Untuk itu pemberian rangsangan pendidikan, bimbingan dan perawata yang tepat akan membantu anak untuk mengoptimalkan segenap lingkup aspek perkembangan anak.

Pendidikan anak usia dini berfungsi untuk membantu tumbuh kembang anak, jasmani rohani agar berkembang sesuai potensinya. Mengingat pada masa ini adalah masa keemasan bagi anak yang akan 
mempengaruhi periode berikutnya. Pendidikan anak usia dini sebagaimana dalam Undang-undang No. 20 Tahun 2003 didefinisikan sebagai upaya pembinaan yang ditujukan kepada anak sejak lahir sampai dengan usia enam tahun yang dilakukan dengan memberi rangsangan pendidikan untuk membantu pertumbuhan dan perkembangan jasmani dan rohani agar anak memiliki kesiapan dalam memasuki pendidikan lebih lanjut. Early childhood education yang dikenal di Indonesia dengan istilah pendidikan anak usia dini adalah pendidikan yang ditujukan bagi anak-anak usia prasekolah dengan tujuan agar anak dapat mengembangkan potensipotensinya sejak dini sehingga mereka dapat berkembang secara wajar sebagai anak. PAUD menjadi spesifik karena pada tahap ini diyakini bahwa anak sedang mengalami tahap perkembangan fisik dan mental yang paling cepat termasuk di dalamnya aspek sosial anak.

Perkembangan sosial merupakan pencapaian kematangan dalam hubungan sosial. Dapat juga diartikan sebagai proses belajar untuk menyesuaikan diri terhadap norma-norma kelompok, moral, dan tradisi, meleburkan diri menjadi satu kesatuan dan saling berkomunikasi dan bekerja sama. Kematangan sosial anak akan mengarahkan pada keberhasilan anak untuk lebih mandiri dan terampil dalam mengembangkan hubungan sosialnya. Perkembangan sosial anak sangat dipengaruhi oleh proses perlakuan atau bimbingan orang tua di keluarga dan guru, kepala sekolah serta tenaga kependidikan lain di sekolah dalam mengenalkan berbagai aspek kehidupan sosial, atau norma-norma kehidupan bermasyarakat atau mendorong dan memberikan contoh kepada anak bagaimana menerapakan norma-norma tersebut dalam kehidupan sehari-hari.

Kesiapan sosial emosional seorang anak merupakan faktor penting bagi keberhasilan pengembangan anak usia prasekolah, keberhasilannya pada tahun- tahun awal di sekolah (kelas satu dan dua sekolah dasar), serta keberhasilan anak dikemudian hari. Hurlock (2000:261) mengungkapkan bahwa anak yang mengikuti pendidikan prasekolah melakukan penye- 
suaian sosial yang lebih baik dibandingkan dengan anak yang tidak mengikuti pendidikan prasekolah. Pendidikan anak usia dini memiliki peran penting sebagai wahana dalam mengoptimalkan tumbuh kembang anak yang mencakup aspek nilai agama dan moral, fisik (motorik kasarhalus), sosial, emosional, kognitif, bahasa, dan seni.

\section{Permasalahan}

Fokus permasalahan ini adalah bagaimana pengembangan aspek sosial anak usia dini di Taman Kanak-Kanak (TK) ABA IV Mangli Jember Tahun 2016?

\section{Anak Usia Dini}

Pada hakekatnya manusia adalah makhluk yang dilahirkan dalam keadaan lemah dan tidak berdaya, namun dengan demikian ia telah mempunyai potensi bawaan yang bersifat laten (Imam Subqi,2016:165). Anak merupakan seorang individu yang unik, bebas, senang bereksplorasi, memiliki rasa ingin tahu yang besar, egosentris, identik dengan dunia bermain, membutuhkan bantuan orang lain, suka meniru, masih polos, masih berkembang, dan kreatif.

Aristoteles (Sri Harini, 2003: 54) menjelaskan anak usia dini adalah masa anak kecil, anak umur 0-7 tahun atau masa bermain. Anak usia dini sebagaimana dalam Undang-undang no. 20 tahun 2003 adalah anak sejak lahir sampai usia 6 tahun. Masa usia dini (0-6 tahun) merupakan masa keemasan (golden age) dimana stimulasi seluruh aspek perkembangan berperan penting untuk tugas perkembangan selanjutnya. Hasil penelitian mengungkapkan bahwa sampai usia 4 tahun tingkat kapabilitas kecerdasan anak telah mencapai 50\%. Pada usia 8 tahun mencapai $80 \%$, dan sisanya sekitar $20 \%$ diperoleh pada saat anak berusia 8 tahun keatas (Dirjen PAUDNI, 2012:1), dan mencapai titik kulminasi pada usia 18 tahun. 
Masa kanak-kanak sebagaimana menurut Aswarni Sujud (1999:24) merupakan masa strategis sekaligus masa kritis. Dikatakan strategis karena masa ini merupakan masa peka untuk memperoleh stimulan dan pembelajaran yang memungkinkan anak dikondisikan untuk memperoleh keberhasilan dalam hidupnya. Dikatakan masa kritis karena jika terjadi salah asuh anak tidak memperoleh stimulan dan perlakuan yang tepat, maka perkembangan anak pada masa selanjutnya akan mengalami gangguan. Dari disini dapat diketahui bahwa masa awal kehidupan anak yaitu usia 0 sampai 6 tahun merupakan masa terpenting dalam rentang kehidupan seseorang anak.

Biechler dan Snowman dalam Sri Harini (2003: 55) menjelaskan anak usia dini atau prasekolah adalah anak yang biasanya mengikuti program prasekolah, program tempat penitipan anak (3 bulan-5 tahun), kelompok bermain (usia 3 tahun) dan Taman Kanak-Kanak (4-6 tahun). Anak usia dini yaitu anak yang dalam tahapan perkembangan sering disebut dengan usia problematis, menyulitkan dan usia bertanya.

Anak usia dini berdasarkan keunikan dan perkembangannya dikelompokkan dalam tahapan: masa bayi lahir sampai 12 bulan, masa batita atau toddler 1 sampai 3 tahun, masa prasekolah usia 3-6 tahun, dan masa kelas awal usia 6 sampai 8 tahun (Mansur, 2009:88). Anak usia dini sebagaimana diungkapkan oleh Piaget berada pada tahapan pra operasional yaitu tahapan ketika anak belum menguasai operasi mental logis. Periode ini ditandai dengan berkembangnya kemampuan menggunakan sesuatu untuk mewakili sesuatu dengan menggunakan symbol-simbol. Melalui kemampuan tersebut anak mampu berimajinasi atau berfantasi dengan berbagai hal (Barwami \& Novan Ardy Wiyani, 2012:85).

Dari beberapa definisi yang ada dapat diambil suatu pengertian bahwa anak-anak usia dini adalah anak-anak di bawah usia sekolah atau yang belum memasuki usia sekolah dasar, yaitu 0-6 tahun, namun 
sudah bisa dimasukkan pada pendidikan anak prasekolah baik TK atau RA, maupun pendidikan non formal (kelompok bermain, tempat penitipan anak, pos PAUD, Bina Keluarga Balita dan sebagainya). Masa usia dini (0-6 tahun) merupakan masa keemasan (golden age) yang akan mempengaruhi perkembangan anak selanjutnya, sehingga diperlukan upaya pembinaan yang tepat sehingga anak dapat mengembangkan potensinya secara holistik baik moral dan agama, fisik/motorik, kognitif, sosial, emosional, dan seni.

\section{Perkembangan Sosial Anak Usia Dini}

Perkembangan adalah perubahan mental yang berlangsung secara bertahap dan dalam waktu tertentu, dari kemampuan sederhana menjadi kemampuan yang lebih kompleks. Perkembangan merupakan proses perubahan atau peningkatan sesuatu kearah yang komplek dan bersifat psikis. Perkembangan dan pertumbuhan merupakan dua hal yang berbeda akan tetapi perkembangan berhubungan dengan pertumbuhan.

Hurlock (2000:250) mengatakan bahwa perkembangan sosial adalah perolehan kemampuan berperilaku yang sesuai dengan tuntutan sosial. Sejalan dengan pendapat di atas, menurut pendapat Allen dan Marotz (2010:31) perkembangan sosial adalah area yang mencakup perasaan dan mengacu pada perilaku dan respon individu terhadap hubungan mereka dengan individu lain. Perkembangan sosial merupakan pencapaian kematangan dalam hubungan sosial. Dapat juga diartikan sebagai proses belajar untuk menyesuaikan diri terhadap norma-norma kelompok, moral, dan tradisi, meleburkan diri menjadi satu kesatuan dan saling berkomunikasi dan bekerja sama. Kematangan sosial anak akan mengarahkan pada keberhasilan anak untuk lebih mandiri dan terampil dalam mengembangkan hubungan sosialnya. 


\section{Proses Perkembangan Sosial Anak}

Anak-anak yang memiliki motivasi kuat untuk belajar akan mempunyai masa depan yang cerah diwarnai penemuan, kesempatan, dan kontribusi. Mereka memiliki kecenderungan alami untuk menguasai hal-hal tersebut yang akan membuatnya sukses pada abad ke 21, serta mendapat manfaat dari segala perubahan positif dalam masyarakat. Mereka yang memiliki motivasi belajar yang kuat mungkin saja akan menghadapi kendala-kendala dari sebuah ketidakadilan, tetapi kendala tersebut bukanlah musuhnya. Mereka akan menjadi orang-orang yang paling cocok untuk belajar bagaimana menghadapi kendala tersebut. Mareka akan menjadi orang yang paling mampu berkreasi dan mencapai kesuksesan karena hasil terbaik dalam IPTEK, penelitian, dan kesenian tidak dapat dipaksakan dari hati yang mengerdil.

Anak bukanlah orang dewasa dalam ukuran kecil. Oleh sebab itu, anak harus diperlakukan sesuai dengan tahap-tahap perkembangannya. Hanya saja, dalam praktik pendidikan sehari-hari, tidak selalu demikian yang terjadi. Banyak contoh yang menunjukkan betapa para orang tua dan masyarakat pada umummnya memperlakukan anak tidak sesuai dengan tingkat perkembangananya. Di dalam keluarga orang tua sering memaksakan keinginannya sesuai kehendaknya, di sekolah guru sering memberikan tekanan (preasure) tidak sesuai dengan tahap perkembangan anak, di berbagai media cetak/elektronika tekanan ini lebih tidak terbatas lagi, bahkan cenderung ekstrim.

Menurut Hurlock (2000:251) untuk mencapai perkembangan sosial dan mampu bermasyarakat, seorang individu memerlukan tiga proses. Ketiga proses tersebut saling berkaitan, jadi apabila terjadi kegagalan dalam salah satu proses akan menurunkan kadar sosialisasi individu. Ketiga proses ini yaitu: (1) Belajar berperilaku yang dapat diterima secara sosial. Setiap kelompok sosial mempunyai standar masing-masing bagi para anggotanya mengenai perilaku yang dapat diterima. Agar dapat diterima 
dalam suatu kelompok sosial, seorang anak harus mengetahui perilaku seperti apa yang dapat diterima. Sehingga mereka dapat berperilaku sesuai dengan patokan yang dapat diterima. (2) Belajar memainkan peran sosial yang dapat diterima. Setiap kelompok sosial memiliki pola kebiasaan yang telah ditentukan oleh para anggotanya. Pola kebiasaan tersebut tentu saja harus dipatuhi oleh setiap anggota kelompok. Misalnya kesepakatan bersama untuk kebiasaan di kelas antara guru dan murid. (3) Perkembangan proses sosial, untuk bersosialisasi dengan baik, anak harus menyukai orang dan kegiatan sosial dalam kelompok. jika mereka dapat melakukannya, maka mereka akan dengan mudah menyesuaikan diri dan dapat diterima sebagai anggota kelompok sosial tempat mereka bergabung. Proses perkembangan sosial anak menurut Moh Padil dan Triyo Supriyatno (2007: 84) dapat dilakukan melalui 2 cara yaitu pertama, proses belajar sosial, yang sering disebut dengan istilah sosialisasi, dan kedua, melalui pembentukan loyalitas sosial.

Ary H Gunawan (2000: 33), sosialisasi secara sosiologi berarti belajar untuk menyesuaikan diri dengan mores, folkways, tradisi, dan kecakapan-kecakapan kelompok. Sedangkan secara psikologis sosialisasi berarti/mencakup kebiasaan-kebiasaan, perangai, ide, sikap dan nilai. Thomas Ford Hoult (Padil, 2010: 88), mengemukakan bahwa proses sosialisasi "Almost always denots the process where by individuals learn to behave willingly in accordance with the privailing standards of their culture (Sosialisasi adalah proses belajar individu untuk bertingkah laku sesuai dengan standar yang terdapat dalam kebudayaan masyarakat). Belajar sosial berarti belajar memahami dan mengerti tentang perilaku dan tindakan masyarakat melalui interaksi sosial. Pendefinisian proses sosialiasi tidak bisa terlepas dari 3 (tiga) hal yaitu: pertama, Proses sosialisasi adalah proses belajar, yaitu suatu proses akomodasi yang mana individu menahan, mengubah impuls-impuls dalam dirinya dan mengambil oper cara hidup atau kebudayaan masyarakatnya; kedua, pada proses sosialisasi itu, individu mempelajari kebiasaan, sikap, ide-ide, pola-pola nilai dan 
tingkah laku, dalam masyarakat di mana dia hidup; dan ketiga, semua sikap dan kecakapan yang dipelajari dalam proses sosialisasi itu disusun dan dikembangkan sebagai suatu kesatuan sistem dalam diri pribadinya.

Berdasarkan teori sosialisasi seorang anak dapat melakukan proses sosialisasi pasif maupun sosialisasi aktif. Pada teori sosialisasi pasif, anak hanya akan memberi respon rangsangan orang tua, disisi lain anak akan mengabaikan kemungkinan-kemungkinan lain dalam dirinya sehingga anak akan mengalami konflik-konflik. Dengan kata lain, proses penyesuaian diri ketika mendapat rangsangan dari individu lain ketika tidak ada rangsangan tidak akan terjadi sosialisasi. Sebaliknya sosialisasi aktif, sosialisasi yang dilakukan individu terhadap pengembangan peran sosial menjadi penciptaan peran sosial dan pengembangan dari aturanaturan mengenai aturan-aturan menjadi prosedur interpretatif. Media sosialisasi yang berperan penting dalam proses sosialisasi anak yaitu: keluarga, sekolah, lembaga keagamaan, lingkungan sosial, dan media massa. Ciri sosialisasi peride prasekolah antara lain: (1) Membuat kontak sosial dengan orang di luar rumah;(2) Pregang age, artinya anak prasekolah berkelompok belum mengikuti arti sosialisasi yang sebenarnya. Anak mulia belajar menyesuaikan diri dengan harapan lingkungan sosialnya; (3) Hubungan dengan orang dewasa; (4) Hubungan dengan teman sebaya;(5) 3-4 tahun anak mulai bermain bersama. Anak mulai ngobrol selama bermain, memilih teman selama bermain dan mengurangi tingkahlaku bermusuhan.

Perkembangan kesetiaan sosial ini muncul berkat kesadaran individu terhadap kehidupan di tengah-tengah masyarakat. Masyarakat sumber kesetiaan bagi anggotanya. Sebab-sebab munculnya kesetiaan sosial diantaranya adalah partisipasi sosial, komunikasi, dan kerjasama individu dalam kehidupan kelompok. Anak kecil yang hadir di tengahtengah kehidupan masyarakat secara diterima sebagai anggota baru. Dengan demikian, perkembangan kesetiaan sosial mengikuti pola 
sebagai berikut: kerjasama menimbulkan kepuasan dan dari kepuasan menimbulkan kesetiaan sosial. Bentuk kesetiaan sosial berkembang menjadi semakin kompleks kepada kelompok yang makin besar. Kesetiaan sosial dimulai dari keluarga teman sebaya, dan sekolah. Kemudian, kesetiaan sosial berkembang seiring dengan perkembangan kedewasaan seseorang, semakin dewasa seseorang semakin berkembang kesetiaan sosialnya kepada kelompok pekerjaaan, kelompok agama, perkumpulan (organisasi), baik kemasyarakatan maupun bangsa. Perkembangan yang lebih luas dan besar ini disebut lingkungan sekunder, dimana seluruh anggota kelompok mencerminkan seorang inividu yang kompleks.

\section{Ciri-ciri Sosial Anak Usia Dini}

Soemarti (Sri Harini dan Aba Firdaus, 2003: 60) menyebutkan ciri sosial anak prasekolah secara umum antara lain: memiliki satu atau dua sahabat tetapi cepat berganti, bisa menyesuaikan diri secara sosial, sudah mau bermain dengan temannya dalam kelompok kecil dan kurang terorganisir dengan baik, perselisihan kerap terjadi akan tetapi hanya berlangsung beberapa saat kemudian mereka baikan kembali, anak yang lebih kecil sering bermain bersebelahan dengan anak yang lebih besar, dan anak-anak telah menyadari peran jenis kelamin dan sex typing.

Ciri perkembangan sosial pada masa ini ditandai oleh meluasnya lingkungan sosial. Anak-anak mulai melepaskan diri dari keluarga, mendekatkan diri pada orang lain disamping anggota keluarga (Rahayu, dkk, 1998:183). Anak-anak memasuki dunia dengan wawasan (perceptual) dan kemampuan motorik yang mengejutkan, sehingga masa kecil sebagai saat ideal untuk mempelajari keterampilan motorik dan seperangkat kemampuan untuk berinteraksi dengan orang lain, dan kapasitas untuk belajar siap digunakan begitu mereka lahir (Ebbeck, 1997:123).

Aspek perkembangan sosial pada anak usia dini diharapkan memiliki kemampuan dan hasil belajar yang dicapai meliputi: kemampuan 
mengenal lingkungan sekitar, mengenal alam, mengenal lingkungan sosial, peranan masyarakat, dan menghargai keragaman sosial budaya yang ada di sekitar anak dan mampu mengembangkan konsep diri, sikap positif terhadap belajar, memiliki kontrol diri yang baik, serta memiliki rasa empati pada orang lain.

Erikson mengidentifikasi perkembangan sosial anak sebagai berikut (1) Tahap 1 : Basic trust vs Mistrust (percaya vs curiga), usia 0-2 tahun pada tahap ini, apabila anak mendapatkan pengalaman yang menyenangkan akan tumbuh rasa percaya diri dan apabila mendapatkan pengalaman yang kurang menyenangkan akan timbul rasa curiga. (2) Tahap 2: Autonomy vs Shame \& Doubt (mandiri vs ragu), anak usia 2-3 tahun apabila sudah merasa mampu menguasai anggota tubuhnya dapat menimbulkan otonomi, sebaliknya apabila lingkungan terlalu banyak bertindak untuk anak akan menimbulkan rasa malu dan ragu-ragu. (3) Tahap 3: Initiative vs Guilt (iniiatif vs bersalah), anak usia 4-5 tahun, anak dapat menunjukkan mulai lepas dari orang tua anak berinteraksi denagn lingkungannya. Kondisi lepas dari orang tua menimbulkan rasa berinisiatif, dan sebaliknya menimbulkan rasa bersalah.(4) Tahap 4: percaya diri vs rasa rendah diri, usia 6 tahu sampai pubertas, anak telah dapat melaksanakan tugas-tugas perkembangan untuk menyiapkan diri memasuki masa dewasa sehingga perlu memiliki keterampilan tertentu. Apabila anak menguasai keterampilan tertentu dapat menumbuhkan rasa percaya diri, dan apabila tidak akan menumbuhkan rasa rendah diri.

Menurut Piaget ciri perkembangan sosial anak usia 4-6 tahun (taman kanak-kanak) sebagai berikut (1) Usia 4 tahun, perkembangan sosial antara lain: sangat antusias, lebih menyukai bekerja dengan 2 atau 3 teman yang dipilih, suka memakai baju orang tua/orang lain, dapat membereskan alat permainannya, tidak menyukai apabila dipegang tangannya dan menarik perhatian karena di puji. (2) Usia 5 tahun, perkembangan sosial antara lain: senang di rumah dekat dengan ibu, ingin di suruh/ 
senang membantu, senang pergi ke sekolah, kadang-kadang malu dan sukar bicara, bermain dengan kelompok 2 atau 5 orang, serta bekerjanya terpacu oleh kompetisi dengan anak lain. (3) Usia 6 tahun, perkembangan sosial meliputi: mulai terlepas dari sang ibu, menjadi pusatnya sendiri, mementingkang diri sendiri, antusiasme yang impulsif, dapat menjadi faktor penggnaggu di kelas, menyukai pekerjaannya dan selalu ingin membawa pulang.

Perilaku prososial anak usia dini sebagaimana dalam Permendikbud nomor 137 tahun 2014 tentang Standar Pendidikan Anak Usia Dini mencakup (1) Kemampuan bermain dengan teman sebaya, (2) Memahami perasaan, (3) Merespon, (4) Berbagi, (5) Menghargai hak dan pendapat orang lain, (6) Kooperatif,(6) Toleran, dan (7) Berperilaku sopan.

Hurlock (dalam Susanto, 2011: 139) menjelaskan bahwa pola perilaku sosial pada anak usia dini meliputi: (1) Meniru, anak meniru sikap dan perilaku orang yang ia kagumi, (2) Persaingan, keingingan untuk mengungguli dan mengalahkan orang lain sudah terlihat ketika anak berusia 4 (empat) tahun.(3) Kerjasama. Anak pada usia 3 tahun akhir sudah mulai bermain bersama/kooperatif dengan teman sebaya.(4) Simpati. Simpati membutuhkan pengertian tentang perasaan-perasaan dan emosi orang lain. Dunia anak adalah bermain, semakin banyak kontak bermain semakin cepat simpati akan berkembang. (5) Empati, (6) Dukungan sosial. Berakhirnya masa kanak-kanak dukungan dari temanteman menjadi lebih penting daripada persetujuan orang dewasa. (7) Membagi. Anak mengetahui bahwa salah satu cara untuk memperoleh persetujuan sosial adalah dengan membagi apa yang ia miliki dengan anak lain. Anak akan rela berbagi mainan, makanan dan sebagainya untuk mempererat pertemanan. (7) Perilaku akrab. Bentuk perilaku akrab diperlihatkan anak dengan canda gurau, tawa riang, memeluk, merangkul, gendong dan sebagainya. 


\section{Keterampilan Sosial-emosional Anak Usia Dini}

Sujiono(Susanto, 2011:140)menjelaskantentang alasan pentingnya seorang anak mempelajari berbagai perilaku sosial diantaranya (1) Agar anak dapat belajar bertingkahlaku sesuai dengan harapan masyarakat, (2) Agar anak mampu memainkan peranan sosial yang bisa diterima kelompoknya, (3) Agar anak dapat mengembangkan sikap sosial yang baik terhadap lingkunganya yang merupakan modal untuk suksesnya dalam hidup bermasyarakat, (4) Agar anak mampu menyesuaikan diri secara baik, sehingga anak dapat diterima oleh lingkungan sosialnya.

Children Resources International (Susanto, 2011: 143) mengemukakan bahwa keterampilan sosial-emosional anak usia 3 samapi 4 tahun antara lain: a) memilih teman bermain; b) memulai interaksi sosial dengan anak lain; c) berbagi mainan atau makanan; d) meminta ijin untuk memakai benda orang lain; e) mengekspresikan emosi melalui beberapa tindakan, kata-kata, dan ekspresi wajah; f) menunggu atau menunda keinginan selama lima menit; g) menikmati kedekatan sementara dengan salah satu teman; h) menunjukkan kebanggaan terhadap keberhasilannya; i) dapat membuat sesuatu karena imajinasi dominan; dan j) memecahkan masalah dengan teman sekelas melaui proses pergantian, persuasi, dan negosiasi.

Keterampilan sosial-emosional anak usia 3 sampai 4 tahun menurut Auerbach (Susanto, 2011:143) meliputi: a) mulai menunjukkan beberapa kontrol diri; b) dapat membuat pilihan sederhana; c) berusaha menyenangkan orang dan menyesuaikan diri; d) ledakan kemarahan bisa terjadi; e) kecemasan imajiner (mungkin pada pada kegelapan, anjing, dan sebagainya); f) rasa ingin tahu meningkat dengan cepat; g) frustasi dengan hambatan; h) menikmati pujian; i) responsif pada petunjuk lisan; j) senang berlari dengan anak-anak lain; dan k) membedakan anak perempuan dan laki-laki. 
INJECT: Interdisciplinary Journal of Communication, Vol.2, No.1, Juni 2017: h. 99-122

Faktor yang Mempengaruhi Perkembangan Sosial Anak

Anak dilahirkan belum bersifat sosial, artinya anaktersebut belum memiliki kemampuan untuk bergaul dengan orang lain. Untuk mencapai kematangan sosial, anak harus belajar cara menyesuaikan diri dengan orang lain. Kemampuan ini diperoleh anak melalui berbagai kesempatan atau pengalaman bergaul dengan orang-orang di lingkungannya, baik orang tua, saudara, teman sebaya atau orang dewasa lainnya.

Menurut Hurlock (2000:256) perkembangan sosial anak dipengaruhi oleh dua hal yaitu pertama, lingkungan keluarga dan kedua, lingkungan di luar rumah. (1) Keluarga; Keluarga merupakan lingkungan pertama dan utama yang memberikan pengaruh terhadap berbagai aspek perkembangan anak, termasuk perkembangan sosialnya. Perkembangan sosial anak sangat dipengaruhi oleh proses perlakuan atau bimbingan orang tua dalam mengenalkan berbagai aspek kehidupan sosial, atau normanorma kehidupan bermasyarakat atau mendorong dan memberikan contoh kepada anaknya bagaimana menerapakan norma-norma tersebut dalam kehidupan sehari-hari. (2) Lingkungan di luar rumah, Hurlock (2000; 257) mengatakan bahwa pengalaman sosial awal di lingkungan luar keluarga melengkapi pengalaman di lingkungan keluarga. Sekolah merupakan salah satu lingkungan di luar keluarga yang mempengaruhi berkembangnya sikap sosial anak. Menurut pendapat sunarto dan Agung Hartono (2002: 132), pendidikan di sekolah merupakan proses sosialisasi anak yang terarah. Penanaman norma perilaku yang benar secara sengaja diberikan kepada peserta didik yang belajar di lembanga pendidikan (sekolah). Proses pengoperasian ilmu yang normatif dalam pendidikan, akan memberikan warna kehidupan sosial anak di dalam masyarakat dan kehidupan mereka yang akan datang. Guru akan mulai memasukkan pengaruh terhadap sosialisasi anak. Kepada peserta didik, akan dikenalkan norma-norma lingkungan dekat, dikenalkan pula norma-norma kehidupan bermasyarakat. Upaya yang dapat dilakukan oleh guru untuk mengembangkan aspek sosial anak usia dini menurut 
Martini Jamaris (2002: 83) antara lain; pertama, menimbulkan rasa aman pada anak dan menciptakan suasana yang baik di dalam kelas maupun luar kelas; kedua, menciptakan perilaku positif di dalam dan diluar kelas baik dalam tindakan, perkataan, atau perilaku lainnya; ketiga, memberikan kesempatan pada anak untuk menentukan pilihannya (apabila pilihan anak tidak tepat atau ditolak maka dijelaskan alasannya); keempat, memberikan kesempatan kepada anak untuk berani menyatakan pendapatnya baik bersifat penolakan maupun yang mendukung dengan cara-cara positif; dan kelima, menyediakan sarana prasarana yang mendukung program pembentukan perilaku sosial anak.Moh Padil dan Triyo Supriyatno (2007:105) menjelaskan bahwa perkembangan sosial anak bergantung pada dua hal yaitu pertama, perkembangan biologis (contoh makanan atau minuman, perlindungan orang tua kepada bayi dan sebagainya); dan kedua, perkembangan personal sosial meliputi pengalaman dan pengaruh orang lain. Perkembangan sosial anak dipengaruhi oleh 4 (empat) hal yaitu pemberian kesempatan bergaul dengan orang lain di sekitar anak; adanya minat dan motivasi untuk bergaul; adanya bimbingan dan pengajaran dari orang lain yang dianggap model bagi anak, dan adanya kemampuan komunikasi secara baik yang dimiliki anak (Ahmad Susanto, 2011: 156). Dari beberapa pendapat yang ada dapat diketahui bahwa faktor yang mempengaruhi perkembangan sosial anak berasal dari dalam diri anak (faktor internal), dan dari luar diri anak (faktor eksternal). Wujud perkembangan kemampuan sosial anak dapat dilihat misalnya pada saat anak bermain, anak rela berbagi mainan dengan teman sebayanya mentaati aturan, saling tolong menolong dalam melakukan sesuatu,dan sebagainya.

\section{Taman Kanak-kanak (TK)}

Taman Kanak-Kanak (TK) adalah salah satu bentuk pendidikan anak usia dini jalur pendidikan formal yang memberikan layanan pendidikan bagi anak usia 4-6 tahun, untuk membantu pertumbuhan dan 
perkembangan anak, agar kelak siap memasuki pendidikan lebih lanjut (Dirjen PAUDNI, 2012: 6). TK adalah bentuk satuan pendidikan bagi anak usia dini pada jalur pendidikan formal yang menyelenggarakan program pendidikan bagi anak usia empat tahun sampai enam tahun (Yuliani Nuraini Sujiono, 2013: 22). Sasaran pendidikan TK adalah anak usia 4-6 tahun, yang dibagi kedalam dua kelompok belajar berdasarkan usia yaitu kelompok A untuk anak usia 4-5 tahun dan kelompok B untuk anak didik usia 5- 6 tahun.

Fungsi pendidikan Taman Kanak-kanak adalah membina, menumbuhkan, mengembangkan seluruh potensi anak secara optimal sehingga terbentuk perilaku dan kemampuan dasar sesuai dengan tahap perkembangannya agar memiliki kesiapan untuk memasuki pendidikan selanjutnya.

\section{Metodologi Penelitian}

Penelitian ini merupakan penelitian kualitatif dengan pendekatan fenomenologis naturalistik, bermaksud mengembangkan pengertian tentang individu dan kejadian dengan memperhitungkan konteks yang relevan. Penelitian ini menggambarkan, mengungkap, dan menjelaskan pengembangan sosial anak usia dini di Taman Kanak-Kanak (TK) ABA IV Mangli Jember tahun 2016. Penelitian ini dilakukan di Taman Kanak-Kanak (TK) ABA IV Mangli Jember selama 1 (satu) bulan, dalam penetapan subyek penelitian menggunakan purposive sampling. Subyek penelitian dipilih subyek pertama sebagai informan kunci yaitu informan yang didasarkan pertimbangan tertentu memenuhi syarat sebagai informan yang sangat mengetahui aspek-aspek permasalahan yang diteliti, bahkan sebagai pelaku dalam pengembangan aspek sosial anak. Subyek penelitian sebagai informan dalam penelitian ini terdiri dari guru, kepala sekolah, siswa, orang tua siswa Taman Kanak-Kanak (TK) ABA IV Mangli Jember. 
Teknik pengumpulan data yang dipakai adalah observasi non partisipan, wawancara mendalam dan teknik dokumentasi. Teknik observasi dimaksudkan untuk memperoleh data secara langsung dan lebih akurat. Analisis data menunjuk pada kegiatan mengorganisasikan data ke dalam susunan-susunan tertentu dalam rangka penginterpretasian data. Model analisis interaktif (component of analysis: Interactive model) dapat digambarkan sebagai berikut:

\section{Analisa Data Secara Interaktif}

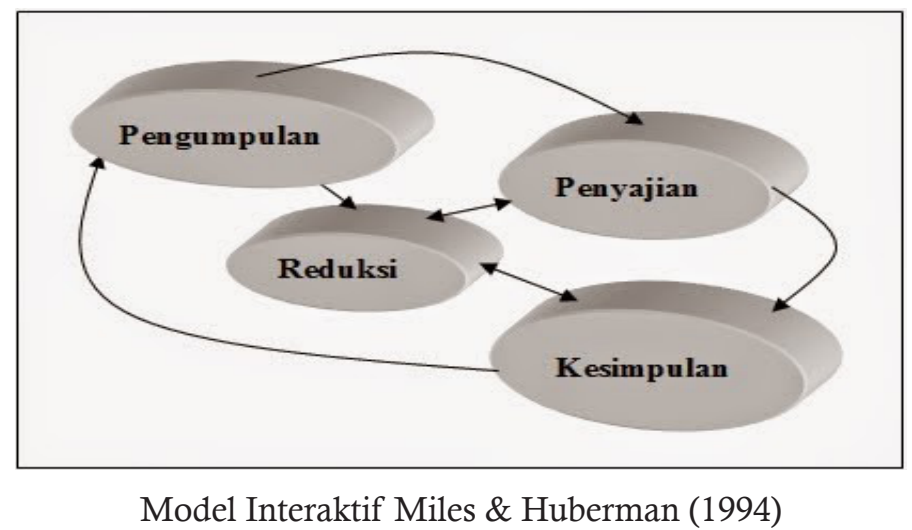

(Sumber: Miles \& Huberman, 1994). Analisa Data Kulitatif

\section{Kemampuan Sosial Anak Usia Dini di Taman Kanak-kanak ABA IV Man- gli Jember}

Berdasarkan hasil wawancara, observasi dan dokumentasi diketahui bahwa kemampuan sosial anak di Taman Kanak-Kanak ABA IV Mangli meliputi: kemampuan bergaul, bersosialisasi dan komunikasi dengan teman dan guru secara baik, bekerjasama, bersabar menunggu giliran, peduli dan menolong teman yang mengalami kesulitan mengerjakan tugas di kelas, berbagi makanan dan mainan, mengalah pada teman dan bertanggungjawab. Kemampuan sosial anak di Taman Kanak-Kanak ABA IV Mangli sesuai dengan Standar Tingkat Percapaian Perkembangan Anak (STPPA) aspek sosial pada anak usia 4 sampai 6 tahun. 
Perilaku prososial anak dalam Permendikbud nomor 137 tahun 2014 tentang Standar Pendidikan Anak Usia Dini mencakup: a). kemampuan bermain dengan teman sebaya, b). Memahami perasaan, c) merespon, d). berbagi, e). menghargai hak dan pendapat orang lain, f). kooperatif, g). koleran, dan h). berperilaku sopan. Hurlock (dalam Susanto, 2011: 139) menjelaskan bahwa pola perilaku sosial pada anak usia dini meliputi: meniru, persaingan, keingingan untuk mengungguli dan mengalahkan orang lain, kerjasama dengan teman sebaya, simpati. Empati, dukungan sosial, membagi (anak rela berbagi mainan, makanan dan sebagainya), dan perilaku akrab.

Taman Kanak-Kanak (TK) sebagai bentuk layanan Pendidikan Anak usia dini jalur formal memiliki peran penting untuk mengoptimalkan semua aspek perkembangan anak. Sri Harini dan Aba Firdaus al-Halwani (2003: 111) menjelaskan Taman Kanak-kanak dapat memberikan kontribusi positif bagi perkembangan sosial anak karena suasana TK sebagian masih seperti suasana keluarga; tata tertib TK masih longgar; anak berkesempatan untuk aktif bergerak, bermain, dan riang gembira yang kesemuanya memiliki nilai pedagogis; serta anak dapat bergaul dengan teman sebaya. Fungsi pendidikan Taman Kanak-kanak adalah membina, menumbuhkan, mengembangkan seluruh potensi anak secara optimal sehingga terbentuk perilaku dan kemampuan dasar sesuai dengan tahap perkembangannya agar memiliki kesiapan untuk memasuki pendidikan selanjutnya.

Anak usia dini perlu diberikan stimulus yang tepat. Mengingat Anak usia dini adalah anak yang dalam tahapan perkembangan sering disebut dengan usia problematis, menyulitkan dan usia bertanya (Biechler dan Snowman dalam Sri Harini, 2003: 55). Hal tersebut dipertegas oleh Aswarni Sujud (1999:24) bahwa masa kanak-kanak merupakan masa strategis sekaligus masa kritis. Dikatakan strategis karena masa ini merupakan masa peka untuk memperoleh stimulan dan pembelajaran yang 
memungkinkan anak dikondisikan untuk memperoleh keberhasilan dalam hidupnya. Dikatakan masa kritis karena jika terjadi salah asuh anak tidak memperoleh stimulan dan perlakuan yang tepat, maka perkembangan anak pada masa selanjutnya akan mengalami gangguan.

\section{Metode Mengembangkan Aspek Sosial Anak Usia Dini di Taman Kanak- Kanak ABA IV Mangli Jember}

Berdasarkan hasil wawancara dan observasi dapat diketahui bahwa metode yang digunakan dalam mengembangkan aspek sosial anak di TK ABA IV Mangli Jember yaitu bermain, bermain peran (role playing), tutor sebaya, keteladanan dan metode pembiasaan yang dilakukan di kelas maupun outdoor di luar kelas.

Metode bermain dan bermain peran (roleplaying)merupakan metode yang penting dalam mengembangkan 6 lingkup aspek perkembangan anak termasuk aspek sosial anak. Dunia anak adalah dunia bermain. Metode bermain adalah metode yang menerapkan permainan tertentu sebagai pembelajaran anak. Piaget menjelaskan bahwa bermain terdiri atas tanggapan yang diulang sekedar untuk kesenangan fungsional. (Muhamad Fadilah, 2012:168). Bermain dilakukan untuk kesenangan, tanpa mempertimbangkan hasil akhir, dilakukan secara suka rela dan lebih didorong oleh faktor intriksik. Bermain memiliki fungsi bagi anak yaitu: mengembangkan keseimbangan fisik, kognitif, sosial-emosional, bahasa dan komunikasi; menghayati berbagai pengalaman yang diperoleh melalui kehidupan sehari-hari; mengantisipasi peran yang akan dijalankan anak dimasa yang akan datang; menyempurnakan berbagai kemampuan melalui berbagai keterampilan fisik, kognitif, sosial-emosional, bahasa dan komunikasi, serta pembentukan perilaku positif.

Selain metode bermain, tutor sebaya digunakan untuk mengembangkan aspek sosial anak di TK ABA IV Mangli. Dalam tutor sebaya anak yang pandai membantu dan mengajari anak lain (temannya) yang mengalami kesulitan dalam mengerjakan tugas yang diberikan oleh 
guru. Kegiatan tersebut dapat mengasah kemampuan sosial anak yaitu kepedulian terhadap orang lain yang mengalami kesulitan.

Disisi lain guru di TK ABA IV menggunakan keteladanan dan pembiasaan dalam mengembangkan aspek sosial anak usia dini. Kedua metode ini dinilai mengena untuk mengembangkan 6 (enam) lingkup aspek perkembangan anak usia dini termasuk aspek sosial. Metode keteladanan adalah metode pendidikan/pembelajaran yang didasarkan pada contoh tingkah laku yang ditunjukkan oleh orang tua maupun pendidik. Dalam konteks pendidikan anak usia dini, metode keteladanan dapat ditunjukkan dan dilakukan oleh seorang pendidik. Sebab, salah satu karakteristik dan keunikan anak usia dini ialah suka meniru (Muhamad Fadilah, 2012:167). Oleh karena itu, ketika pendidik (orang tua, guru) menunjukkan sikap-sikap yang baik dalam kesehariannya, khususnya dalam proses pembelajaran, pasti secara otomatis akan diamati dan diikuti oleh anak didik. Sedangkan pembiasaan yaitu melakukan sesuatu secara berulang-ulang. Maksudnya apa yang dilakukan anak dalam pembelajaran diulang terus menerus sampai ia dapat benar-benar memahaminya dan dapat tertanam di dalam hatinya. Dengan adanya kegiatan pembiasaan yang terencana dengan baik tentunya berpengaruh terhadap hasil yang diperoleh dalam mendidik anak, sehingga anak dapat memahami dan membiasakan kegiatan yang telah diajarkan. Metode ini sangat baik digunakan karena anak masih suka menerima pembiasaanpembiasaan yang diterapkan pada dirinya dan anak usia dini belum banyak terpengaruh oleh dunia luar.

\section{Peran guru dalam mengembangkan aspek sosial anak usia dini di Taman Kanak-Kanak ABA IV Mangli Jember}

Dari penyajian data sebelumnya diketahui bahwa peran guru dalam mengembangkan aspek sosial anak usia dini di TK ABA IV Mangli antara lain: guru berperan sebagai fasilitator dan memotivasi kegiatan bermain kolektif anak, guru berperan sebagai pemimpin yang baik bagi 
anak yang selalu memberi panutan dalam tindakan, ucapan maupun sikap, memberikan arahan, dan bimbingan dalam sosialisasi. Guru juga menyediakan suasana yang aman dan nyaman bagi anak. Guru menjalin kedekatan dengan anak, dan mengakrabkan anak yang satu dengan anak lain. Selain itu, untuk anak yang mengalami kesulitan dalam bersosialisasi guru melakukan pendekatan dan kerjasama dengan orang tua.

Upaya yang dapat dilakukan oleh guru untuk mengembangkan aspek sosial anak usia dini menurut Martini Jamaris (2002: 83) antara lain; pertama, menimbulkan rasa aman pada anak dan menciptakan suasana yang baik di dalam kelas maupun luar kelas; kedua, menciptakan perilaku positif di dalam dan di luar kelas baik dalam tindakan, perkataan, atau perilaku lainnya; ketiga, memberikan kesempatan pada anak untuk menentukan pilihannya (apabila pilihan anak tidak tepat atau ditolak maka dijelaskan alasannya); keempat, memberikan kesempatan kepada anak untuk berani menyatakan pendapatnya baik bersifat penolakan maupun yang mendukung dengan cara-cara positif; dan kelima, menyediakan sarana prasarana yang mendukung program pembentukan perilaku sosial anak. Guru memiliki peran penting dalam proses belajar sosial anak. Sekolah menjadi tempat sosialisasi bagi seorang anak. Guru akan mulai memasukkan pengaruh terhadap sosialisasi anak. Anak akan dikenalkan norma-norma lingkungan dekat, dikenalkan pula normanorma kehidupan bermasyarakat. Dengan kata lain, di sekolah seorang anak akan belajar bertingkah laku, belajar kebisaan-kebiasaan, nilai, norma, cara berpikir, bertindak, dan sebagainya dari seorang guru.

Bagi seorang anak guru merupakan model panutan yang akan ditiru oleh seorang anak. Adanya bimbingan dan pengajaran dari guru yang dianggap model bagi anak akan berpengaruh pada perkembangan sosial anak. Hal tersebut sejalan dengan pendapat Ahmad Susanto (2011: 156) bahwa perkembangan sosial anak dipengaruhi oleh 4 (empat) hal yaitu pemberian kesempatan bergaul dengan orang lain di sekitar anak; adanya 
INJECT: Interdisciplinary Journal of Communication, Vol.2, No.1, Juni 2017: h. 99-122

\section{Simpulan}

Dari uraian di atas disimpulkan sebagai berikut: (1) Kemampuan sosial anak usia dini di Taman Kanak-Kanak ABA IV Mangli Jember tahun 2016 meliputi: kemampuan bergaul, bersosialisasi dan komunikasi dengan teman dan guru secara baik, bekerjasama, bersabar menunggu giliran, peduli dan menolong teman yang mengalami kesulitan mengerjakan tugas di kelas, berbagi makanan dan mainan, mengalah pada teman dan bertanggungjawab. (2) Metode yang digunakan dalam mengembangkan aspek sosial anak di TK ABA IV Mangli Jember yaitu bermain, bermain peran (role playing), tutor sebaya, keteladanan dan metode pembiasaan yang dilakukan di kelas maupun outdoor di luar kelas. (3) Peran guru dalam mengembangkan aspek sosial anak usia dini di TK ABA IV Mangli Jember antara lain: guru berperan sebagai fasilitator dan memotivasi kegiatan bermain kolektif anak, guru berperan sebagai pemimpin yang baik bagi anak yang selalu memberi panutan dalam tindakan, ucapan maupun sikap, memberikan arahan, dan bimbingan dalam sosialisasi. Guru juga menyediakan suasana yang aman dan nyaman bagi anak. Guru menjalin kedekatan dengan anak, dan mengakrabkan anak yang satu dengan anak lain. Selain itu, untuk anak yang mengalami kesulitan dalam bersosialisasi guru melakukan pendekatan dan kerjasama dengan orang tua dalam mengembangkan sikap sosial anak.

\section{Daftar Pustaka}

Dinas Pendidikan. 2013. Pedoman Pengembangan Pembelajaran (Kurikulum) dan Perangkat Bahan Ajar Pendidikan Anak Usia Dini (PAUD) Holistik Integratif. Pemerintah Provinsi Jawa Tengah

Dirjen PAUDNI. 2012. Pedoman Penyelenggaraan Pendidikan Anak Usia Dini Terpadu. Jakarta: Direktorat PAUDNI

Ebbeck, Majory. 1997. Menyadari dan mengembangkan potensi anak usia dini. Yogyakarta: Makalah terjemahan UNY. 
Gunawan, H Ary. 2000. Sosiologi Pendidikan Suatu Analisis tentang Pelbagai Problem Pendidikan. Jakarta: Rineka Cipta

Hadari Nawawi. 1993. Metodologi penelitian terapan. Yogyakarta: Universitas Gajah Mada.

Harini, Sri dan Aba Firdaus al-Halwani. 2003. Mendidik anak sejak dini. Yogyakarta: Kreasi Wacana.

Hurlock, Elizabeth B. 1978. Child Development (terj. Med Meitasari Tjandrasa). New York: Mc Graw Hill.

Imam Subqi, "Pola Komunikasi Keagamaan dalam Membentuk Kepribadian Anak", INJECT (Interdisciplinary Journal of Communication), Vol 1 No 2 Desember 2016.

Jamaris, Martini. 2002. Perkembangan dan Pengembangan Anak Usia Taman Kanak-Kanak; Pedoman bagi Orang Tua dan Guru. Jakarta: PT Grasindo

Mansur. 2009. Pendidikan Anak Usia Dini dalam Islam. Yogyakarta: Pustaka Pelajar

Miles, Matthew B. and Huberman. 1994. Qualitative data analysis: An expanded sourcebook. London: Sage publications.

Moleong, Lexy. (2000). Metodologi penelitian kualitatif. Bandung: PT Remaja Rosdakarya

Nasution, S. (1988). Metode penelitian naturalistik-kualitatif. Bandung: Tarsito.

Novan Ardy Wiyani \& Barmawi. 2012. Format PAUD Konsep, Karakteristik, dan Implementasi Pendidikan Anak Usia Dini. Yogyakarta: ArRuzzmedia.

Padil, Moh dan Supriyatno, Triyono. 2010. Sosiologi Pendidikan. Malang: UIN Maliki Press

Permendikbud No.137 tahun 2014 Tentang Standar Pendidikan Anak Usia Dini

Rahayu, et al. 1998. Psikologi Perkembangan Pengantar dalam Berbagai Bagiannya. Yogyakarta: Gajah Mada University Press 
INJECT: Interdisciplinary Journal of Communication, Vol.2, No.1, Juni 2017: h. 99-122

Sekretariat Negara RI, Undang-undang No. 20 Tahun 2003 Tentang Sintem Pendidikan Nasional

Sujud, Aswarni. 1999. Beberapa aspek perkembangan anak dan pendidikan anak usia dini. Yogyakarta: PSW UII

Susanto, Ahmad. 2011. Perkembangan Anak Usia Dini:Pengantar dalam Berbagai Aspeknya. Jakarta: Kencana

Yamin, Martinis dan Sabri Sanan, Jamilah. 2013. Panduan PAUD. Ciputat: Gaung Persada Press Group

Yuliani Nurani Sujiono 2013. Konsep Dasar Pendidikan Anak Usia Dini Jakarta: PT. Indeks.

Yusuf, Syamsu. 2001. Psikologi Perkembangan Anak dan Remaja. Bandung: PT Remaja Rosda Karya 